\section{海峡を渡った討論会一第44回粉体に関する討論会一 The 44th Symposium on Powder Science and Technology}

\author{
鹿毛 浩之 \\ Hiroyuki Kage
}

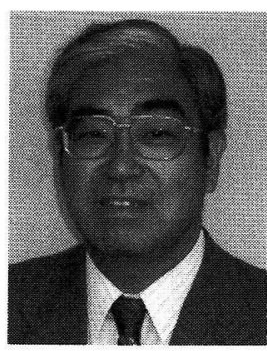

第44回を迎えた「粉体に関する討論会」が平成18年 9 月20日から22日までの3 日間, 北九州市小倉の北九州国 際会議場で開催された。前回の第43回は討論会として初 めて海外の韓国で開催され釜山大学校の崔先生の非常な ご尽力で大きな成功を収めたが，今回は対馬海峡を渡っ た対岸の北九州の地での開催となった。また, 海外を除 いた国内での討論会としても，関門海峡を渡った九州で の開催は平成 7 年に第33回が福岡市天神で開催されて以 来, 実に11年ぶりであった。参加人数は98名で, 講演件 数は特別講演 3 件, ポスター発表 13 件を含む 55 件であっ た。この数字は日韓両国から例年の 2 倍の 112 件の講演 があった前回を除けば，40件代が多いこれまでの討論会 に比べて盛会であったと考えられ，初日の朝から3日目 の夕刻まで活発で充実した討論が続き, 大成功であっ た。

初日午後の特別講演は,「画像で見る粉体の輸送現 象」と題してこの年の春に九州工業大学を定年退職され た富田侑嗣先生が演壇に立たれた。先生からは、ロータ リーフィーダー内およびブロータンク輸送機内の粉体の 流動状態や，水平管内のスラグ流, フラッシング現象な よ゙，多彩な粉粒体の空気輸送における現象について，画 像による観察結果とそこから導き出された知見を多くの 写真を交えて紹介いただいた。二日目には，東北大学大 学院の今野幹男先生に「粒子合成と配列制御」と題して 粒子合成法の開発と微粒子の配列制御について興味深い 研究内容のご講演をいただいた。この講演内容について は, 本特集号に解説をご寄稿いただいたので, 是非ご一 読いただくようお願いしたい。最終日には韓国釜山大学 校の崔堣植先生の特別講演が行われた。先生は19年の 2 月に釜山大学校を定年退職される予定で，これまでのご 研究を「難水溶性薬物の生体利用率改善のための製剂粒 子設計」と題して紹介された。ご講演後にはフロアから 先生の今後のお仕事や日韓交流に関する質問なども出さ れ、これまで討論会にご尽力されてきた先生のお人柄が 滲み出る和やかな講演会となった。

今回の討論会の一般講演の討論主題別の件数内訳を眺 めてみると，(a)粉体・ナノ粒子の生成および機能性微 粒子と新素材: 23 件, (b)バイオ・医薬品・食品・化粧 品と粉体： 7 件, (c)リサイクル・環境・エネルギーと 粉体：11件，(d)粉体一般：11件となっており，粒子の

〈著者紹介〉

昭和 55 年, 京都大学大学院工学研究科化学工学専攻博士課程を単 位取得退学, 同年九州工業大学講師, 以後, 同助教授を経 $\tau$, 平 成 14 年より教授。工学博士。現在, 九州工業大学理数教育支援七 ンター長, 同大産学連撨推進センター長を兼務。専門は, 粒子の 流動化機構, 流動層による粒子の高機能化, マイクロカプセル化 技術など。
生成および機能性微粒子, 新素材が多数を占めており, 近年の研究内容がこの分野に強くシフトしていることが 窥える。討論主題に関しては，当初「粉体・ナノ粒子の 生成」と「機能性微粒子と新素材」を別テーマとし,さ らに「粉体物性」と「粉体プロセス・シミュレーショ ン」を加えた 7 つのテーマで講演募集を行ったが，「粉 体・ナノ粒子の生成」と「機能性微粒子と新素材」で申 し込まれたものには，両方に類似の内容が分散していた り、第二希望にもう一方の討論主題を挙げているものが 多かったりして、両者の分類が難しかったため, プログ ラム編成時に一つにまとめざるを得なかった。さらに，

「粉体物性」と「粉体プロセス・シミュレーション」の 2 テーマを希望するものは共に件数が極めて少なく，他 の主題に振り分けたため最終プログラムでは (a)から (d) の 4 主題となってしまった。このように講演にテーマの 偏りがあったことが今回の大きな特徴であり，現在の研 究動向を反映しているとも考えられるが, 当初の主題の 設定にも問題があったのではないかと反省している。

また，久しぶりの九州での開催ということで，九州か ら多くのご参加が得られたのも今回の特徵であろう。特 に産総研の九州センターからは 4 件のご講演をいただ き，本特集号にもこ投稿いただいた。また，荒川正文先 生には遙々九州までお出向きいただき,十ノ粒子濃厚ス ラリ一の曳系性と粒子分散状態についてご発表を頂い た。先生のお人柄を表すご丁綮な実験と，そこから得ら れたたくさんのデー夕を紹介されながらのお話は，私だ けでなく多くの参加者に強い感銘を与えたのではないか と思う。

最後に、「粉体に関する討論会」の現状を知っていた だくために，初日終了後に開催された世話人会での話題 をいくつかご紹介し、この稿を閉じたい。本討論会は創 設以来、母体となる学会を持たず複数の学協会の共催と しての支援の元に，世話人会で開催準備を行って今日ま で会を維持してきた。しかしこの数年, 各学協会の会計 事情からか，共催の辞退が相次いでおり，今回の共催団 体は 7 学協会のみと, 4 年前の第40回に比へ半減してし まった。今回は北九州国際会議場での開催により北九州 市より会場費にほぼ匹敵する援助を頂くことができたの で，何とか少額の黒字にまで漕き着けたか，次回からは 参加費の値上げを考えざるを得なくなった。この窮状を 是非ご理解いただき，今後とも討論会へのご協力を賜り たい。また，世話人会のメンバーの中には，定年退職を 迎えられ世話人の辞退を申し出られる先生がこの数年目 立ってきており，世話人の交代についても話し合われ た。新しいメンバーを迎え若返りつつある世話人会の今 後と、討論会のこれからの新しい展開にご期待いただ き, 皆様からは更なる暖かいご支援がいただけるようお 願いしたい。 